\title{
North-South Trade, Knowledge Spillovers and Growth
}

\author{
Rod Falvey \\ University of Nottingham \\ Neil Foster \\ University of Vienna. \\ David Greenaway \\ University of Nottingham
}

\begin{abstract}
The endogenous growth literature has stimulated empirical research into links between trade and growth in general and international knowledge spillovers in particular. Results relating to the latter have been mixed and the issue of the appropriate construction of the spillover variable remains contentious. In this paper we develop measures taking account of whether knowledge is a public or private good in the donor and recipient countries, and include these in a dynamic panel model of growth. For a sample of five OECD donor countries and 52 developing recipient countries, we conclude that it matters little whether we treat knowledge as a private or public good in the donor but that spillovers, if they exist, act as a public good in the recipient. We also find that the level of trade is important in facilitating knowledge spillovers from donors to recipients.
\end{abstract}

- JEL Classifications: F43, O30, O40

- Key Words: Knowledge Spillovers, Economic Growth, International Trade, Dynamic Panel Data

\footnotetext{
*Corresponding address: David Greenaway, Professor of Economics and Head of School, Director, Leverhulme Centre for Research on Globaligation and Economic Policy, School of Economics, University of Nottingham, NG7 2RD, United Kingdom, Tel: +44-115-9515467, Fax: +44-115-9515552, E-mail: david.greenaway@nottingham.ac.uk (C)2002-Center for International Economics, Sejong Institution, All Rights Reserved.
} 


\section{Introduction}

The development of theories of endogenous growth has revived interest in the relationship between trade and growth. Recent theories of endogenous technological change (e.g. Romer (1986), Aghion and Howitt (1992) and Grossman and Helpman (1991)) provide a rationale for examining international knowledge spillovers through trade. In a simple variant of these models, final output is produced using intermediate inputs, which may be horizontally or vertically differentiated. $R \& D$ affects output by increasing the number, or improving the quality, of available intermediates. In the absence of trade, a country's output is determined by its own cumulative past $R \& D$ expenditure. With trade a relationship between cumulative $R \& D$ and output remains, but the relevant measure is now the world R\&D stock.

These theories underpin empirical testing of the hypothesis that countries that are more open to imports from partners with a high level of technological knowledge should have higher rates of growth than those that are either closed to trade, or trade with countries with low levels of technological knowledge. While knowledge spillovers can be independent of the actual volume of trade in the simple theoretical models, there are reasons to believe that the trade volume may be important, depending on the extent to which knowledge is a public good in the donor and recipient countries.

The approach used in empirical work has been to construct a "stock of knowledge" for each developed country, and then measure access of other countries to this by weighting these stocks by some measure of the volume or share of bilateral trade. Evidence of knowledge spillovers on trading partners' rates of total factor productivity (TFP) growth have been found among developed countries by Coe and Helpman (1995) $(\mathrm{CH})$, and from developed to developing countries by Coe, Helpman and Hoffmaister (1997) (CHH). But these outcomes depend, inter alia, on the weighting scheme employed, and the construction and interpretation of the foreign knowledge spillover variable remains contentious.

'The recipient countries are: Algeria, Cameroon, Central African Republic, Ghana, Kenya, Malawi, Mauritius, Niger, Senegal, Sierra Leone, South Africa, Sudan, Togo, Tunisia, Zaire, Zambia, Zimbabwe, Costa Rica, Dominican Republic, El Salvador, Guatemala, Haiti, Honduras, Jamaica, Mexico, Nicaragua, Panama, Trinidad and Tobago, Argentina, Bolivia, Brazil, Chile, Colombia, Ecuador, Guyana, Paraguay, Peru, Uruguay, Venezuela, Bangladesh, Myanmar, India, Indonesia, Israel, Korea, Kuwait, Malaysia, Pakistan, Philippines, Sri Lanka, Thailand, and Malta.

${ }^{2}$ The five countries being the United States of America (US), the United Kingdom (UK), Japan, Germany and France. From our data we calculate that the US, UK, Japan, Germany and France make up $90 \%$ of real R\&D expenditure of the 15 OECD countries for which we have data (average 1973-1990). 
In this paper we test for the presence of North-South knowledge spillovers for a sample of 52 developing countries in a model of economic growth ${ }^{1}$. We use data on the manufacturing R\&D expenditure of five $\mathrm{OECD}^{2}$ economies, testing for the presence of knowledge spillovers from these five 'donors' to our 52 'recipients'. The paper differs from $\mathrm{CH}$ and $\mathrm{CHH}$ in important ways however. Firstly, we argue that different weighting schemes are appropriate, depending on whether the knowledge stock is best regarded as a public or private good in the origin country; and whether the knowledge spillover is best regarded as a public or private good in the recipient. The measures that emerge under different assumptions are specified in Section IV. Secondly, we examine the impact of knowledge spillovers on output growth rather than Total Factor Productivity (TFP) growth. Finally, we employ a dynamic panel specification for our model. This technique has advantages over previous methods, since it allows knowledge spillovers to have both a short-run and a long-run impact on growth, and it avoids the problems associated with the non-stationarity of the foreign knowledge variables.

The remainder of the paper is organised as follows. In Section II we discuss the theoretical background concerning knowledge spillovers and the role of trade as a mechanism for the transmission of knowledge. Section III reviews the issues raised by the existing empirical literature, while Section IV describes how we estimate the impact of foreign knowledge spillovers on growth. Section V reports and discusses the results, while Section VI provides some overall conclusions.

\section{Theoretical Background}

It has long been recognised that international technology transfer is an important source of growth, and that the progress of both developed and developing nations may be determined in part by its extent. Yet until the arrival of endogenous growth theory little systematic empirical analysis of this issue had been undertaken. During the 1960s and 1970s a number of authors, in particular Gerschenkron (1962) and Kuznets (1973) talked of the so-called advantage of backwardness'. They argued that being a technological laggard had the advantage that it would be possible to 'borrow' new technology from the leading edge countries. Others, such as Abramovitz (1986), argued that in order to obtain such benefits other factors that affect the ability to adopt such technology needed to be in place, these factors being termed 'social capability'.

From the theoretical literature $\mathrm{CHH}$ identify four channels through which 
international contacts may allow knowledge produced in one country to affect productivity and growth in others. First, they allow a country to employ intermediate and capital goods from abroad, which may enhance the productivity of domestic resources. Second, by increasing communication between countries, they can encourage a more efficient employment of domestic resources through cross-border learning of production methods, product design, organisational structures and market conditions. Third, they can also assist countries inside the technological frontier in imitating the products of countries at the frontier. Finally, they can raise a country's productivity in the development of new technologies or the imitation of foreign technology.

International trade has been highlighted as the major source of such knowledge spillovers and this is our focus here ${ }^{3}$. It is not just whether a country trades that is likely to be important for knowledge spillovers, but also with which countries it trades. In order to benefit from advanced technology and knowledge, the country must trade with countries that are able to provide it with such knowledge. Given that $R \& D$ is concentrated in a small number of developed countries ${ }^{4}$, we expect that developing countries would most likely gain access to knowledge through their trade with the developed world.

When examining the impact of trade on growth in theoretical models, the comparison is usually made between autarky and free trade. Few papers examine how trade policy and changes in openness affect growth. The implication of these theories is that a movement away from autarky will result in positive knowledge spillovers, with the actual volume of trade being unimportant ${ }^{5}$. Imports of any quantity of the relevant products, no matter how small, will result in positive spillovers (see Keller, 1998, 2000). However, if spillovers are not pure public

${ }^{3}$ Other channels are also likely to be the source of such spillovers. The 1999 World Development Report for example suggests additional factors such as FDI, migration, technology licensing and electronic interchange. Xu and Wang (2000) consider the role of FDI in technology diffusion among OECD countries. Similarly, although we concentrate here on the role of imports, the role of exports should not be dismissed as a potential source of knowledge spillovers, for example through customers supplying feedback on the product specification.

${ }^{4}$ Eaton and Kortum (1999) note that in the late 1980s, 80 percent of OECD research scientists and engineers were employed in our five donor countries. Funk (2001) concludes from his empirical analysis of spillovers among the OECD nations, that knowledge flows emerge primarily from the most advanced members.

${ }^{5}$ In the models of horizontal innovation and growth (see for example, Grossman and Helpman, 1991, ch. 3 ), growth depends upon the number of intermediates employed, not on the amount of each intermediate employed. Openness by allowing the importation of a greater variety of intermediates into a country would be expected to raise a country's growth rate, while the level of trade, which indicates the volume of intermediates imported would not affect growth. 
goods, the volume of trade may be important in facilitating their diffusion within the recipient. For developing countries, it is likely that final goods producers will be the main beneficiaries of knowledge spillovers, since the innovation sector will be rather small. In this situation the level of imports may be important by allowing a greater number of firms to benefit from imported technology. The separate roles of the volume of trade and the level of openness are also examined in this paper.

\section{Evidence on International Knowledge Spillovers}

An empirical literature has been in existence for some time examining knowledge spillovers among industries and firms within countries ${ }^{6}$. Recently, in response to the endogenous theories of trade and growth, a literature looking to test for the presence of international knowledge spillovers has emerged. $\mathrm{CH}$ test for their presence among a sample of 22 developed countries over the period 19711990. They study the extent to which a countrys productivity depends upon both domestic and foreign knowledge stocks, where cumulative R\&D expenditures are used as a proxy for the knowledge stock of a country. The foreign knowledge stock is constructed using the weighted sum of trade partners' cumulative $R \& D$ spending. The weights used are bilateral import shares, since it is assumed that it is a country's imports that act as the conduit for knowledge spillovers. The import share weighted foreign knowledge stock is also interacted with the volume of imports to examine the importance of the volume of trade as well as its distribution. They find both the domestic and foreign knowledge stocks to be important sources of productivity growth, although the former has a much larger impact on productivity in the larger countries. Smaller countries, it is argued, tend to be more open and benefit more from foreign knowledge than larger countries ${ }^{7}$. From these results $\mathrm{CH}$ conclude that a relationship between productivity and both the foreign and domestic knowledge stocks exists, with the countries gaining most from foreign knowledge being those that are most open to trade.

$\mathrm{CHH}$ adapt the analysis of $\mathrm{CH}$ to examine the extent of North-South $\mathrm{R} \& \mathrm{D}$ spillovers. They test for the presence of knowledge spillovers through international trade from the 22 developed countries in the $\mathrm{CH}$ study to a sample of 77 developing countries over the period 1971-1990. The method used is similar to

\footnotetext{
${ }^{6}$ See for example Terleckyj (1974) and Griliches (1984).

${ }^{7}$ Though spillovers still occur if the import penetration ratio is corrected for differences in country size. See Crespo et al. (2002).
} 
that by $\mathrm{CH}$, except that they use data averaged over four five-year periods rather than annual data. It is further assumed by $\mathrm{CHH}$ that no R\&D is undertaken in the developing countries, so that no domestic knowledge stock is created. The foreign knowledge stocks for the developing countries are created using a weighted average of the knowledge stocks of the industrial countries, the weights being bilateral import shares of machinery and equipment, as a measure of the imports of capital and intermediate goods. As with the $\mathrm{CH}$ study, this import share weighted foreign knowledge stock is also interacted with the volume of imports. They find that knowledge spillovers from the industrial North to the developing South are substantial. On average, a 1 percent increase in the knowledge stocks of the industrial countries raises productivity growth in the developing countries by 0.06 percent.

The CH methods have been controversial. Keller (1998) compared their results with those obtained from assigning bilateral trade partners randomly and found that regressions based on such simulated data generated on average larger estimated foreign knowledge spillovers, as well as a better fit in terms of $R^{2}$. He concluded that the $\mathrm{CH}$ results may say little about the extent of foreign knowledge spillovers. Coe and Hoffmaister (1999) note that Keller's bilateral import shares are similar to equal weights, or simple averages of trading partners knowledge stocks, suggesting that Keller's weights are not in fact random. They derive three alternative sets of random weight's that do not exhibit this property. When these are used to define the foreign knowledge stock, the foreign knowledge spillover estimates are extremely small and the equations explain less of the variation in productivity than when the true bilateral import shares are used. From these results they conclude that using bilateral import weights or even simple averages to create a measure of foreign knowledge performs better than using random weights, suggesting that a country's productivity is related to its trading partners' knowledge stock. It is noted, however, that the importance of the actual intensity of the trading relationship is an unresolved issue, because of the public good nature of knowledge. Openness to trade appears to be important for the knowledge spillover, but the volume of trade may or may not be.

$\mathrm{CH}$ in their original analysis find that all of their data exhibited a clear trend, but that a co-integrating relationship existed between the variables, which allowed them to consider a relationship between the levels of the variables without having to transform the data. They chose not to report $t$-statistics for their results, because at the time the asymptotic distribution of the $t$-statistic was unknown. Kao et al. 
(1999) argue that since the estimated coefficients are quite small it is not clear whether the estimated coefficients are different from zero. Moreover, given the potential bias in the estimation technique, it is not even clear whether the coefficients have the expected sign. Given recent advances in the understanding of the distribution of the estimators in panel models, Kao et al. examine whether there are indeed significant positive foreign knowledge spillovers using nonstationary panel techniques. They find that the coefficient on the foreign knowledge spillover variable is positive, but insignificant even at the 10 percent level. The impact of domestic knowledge on TFP remains positive and significant however.

\section{Estimating the Impact of Knowledge Spillovers}

Overall the evidence in favour of international knowledge spillovers using this method is mixed. Some studies have found a positive effect of foreign knowledge on productivity and growth, both among developed countries and also from developed to developing countries. Others have found no such relationship. There has also been debate over the appropriate construction of the knowledge stocks. In this section we describe our procedure for testing for the presence of growth enhancing effects of foreign knowledge using a dynamic panel model. We adopt the $\mathrm{CH}$ method to create foreign knowledge stocks and use a number of different weighting schemes for our spillover measures.

\section{A. Empirical Specification}

While the majority of existing empirical studies examine the impact of knowledge spillovers on an index of TFP growth, we find it convenient to adopt a method similar to that employed by Evenson and Singh (1997), examining their impact directly on output growth. In principle the choice between the two should not be too important. But focussing on output growth avoids the errors one might introduce in calculating TFP, and allows a more ready comparison with the majority of growth equations. In particular, we can examine the sensitivity of our knowledge spillover results to the inclusion of other variables found to be significant in growth regressions.

One advantage of modelling knowledge spillovers as affecting output rather than TFP growth, is that some of the other variables normally included in the growth regression may themselves be important conduits for diffusion, but may 
not be adequately accounted for in the TFP calculations. For example, we may expect that the level of human capital would help facilitate knowledge spillovers, since a more educated population is likely to be better able to take advantage of the knowledge available ${ }^{8}$. If this is the case, the coefficients on trade related foreign knowledge spillovers in studies of TFP might be overestimated ${ }^{9}$. Including these other variables separately in our equation would give us more confidence that the results on the foreign knowledge spillover variables are capturing trade related knowledge spillovers and not some other form of knowledge diffusion.

The empirical specification for our growth model follows Greenaway, Morgan and Wright (1997, 1998, 2002), who argue that following the work of Levine and Renelt (1992) and Sala-i-Martin (1997) there has been some convergence concerning the variables included in empirical growth models. Most include as explanatory variables investment share, population growth, initial per capita income and initial human capital variables. Our specification includes these variables together with our measure of foreign knowledge spillovers, a terms of trade variable and a measure of openness. The terms of trade variable is included since our sample consists of developing countries and terms of trade shocks can have a significant impact on growth in this group of countries ${ }^{10}$. The openness measure is included to account for other potential growth-enhancing benefits from openness and is used as a test of the robustness of the spillover variables. Moreover, both Coe and Helpman and $\mathrm{CHH}$ included the ratio of imports to GDP as an additional measure of openness in their model and find the coefficient to be negative, though in general insignificant. We include a measure of openness to test the robustness of this result. The basic specification for our model therefore is:

$$
\begin{gathered}
\Delta \ln y_{i t}=\beta_{1} \Delta \ln S P I L L_{i t}+\beta_{2} \ln y_{i, 65}+\beta_{3}\left(\frac{\operatorname{Inv}}{G D P}\right)_{i t} \\
\beta_{4} \Delta \ln P O P_{i t}+\beta_{5} S E C 25_{i, 65}+\beta_{6} \Delta \ln T T I_{i t}+\beta_{7} S A C H S_{i t}+\Delta e_{i t}
\end{gathered}
$$

where

\footnotetext{
${ }^{8}$ For example Crespo et al. (2002) combine human capital and domestic R\&D capital into a single measure of absoptive capacity which they then interact with the import-share weighted foreign knowledge stocks in their estimating equation.

${ }^{9}$ Moreno and Trehan (1997) however, use measures representing diffusion based on geographical variables and find that including measures of investment, schooling, population growth and initial income in their model alters their estimates on the diffusion variables very little.

${ }^{10}$ See for example Bevan et a.l (1993).
} 


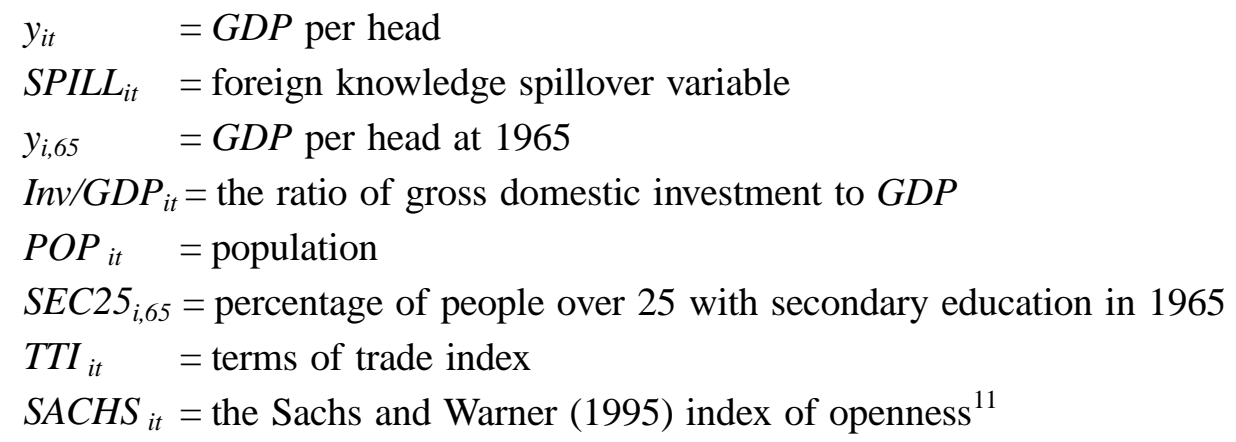

In addition to this specification we also model growth dynamically by introducing a lagged dependent variable. Specifications such as the static model in equation (1) have been used to model movements from one steady state to another, and also to model the transitional effects of various policies, such as trade liberalisation. But if we expect diffusion to have a differential impact on growth in the short-run and long-run, then we may expect equation (1) to be mis-specified. The use of a dynamic model has the advantage that it allows foreign knowledge spillovers to have both a short-run and a long-run impact on growth, which may be expected if full diffusion does not occur immediately. A further advantage relates to the fact, that as discussed below, it is necessary to difference the data in dynamic panel models. The constructed knowledge stocks are non-stationary, which may lead to spurious results when the model is estimated in levels. By differencing the data and removing the problem of non-stationarity, this method will give us confidence in the reported coefficients and standard errors.

Introducing a lagged dependent variable as an explanatory variable does mean that it and the error term are correlated rendering standard estimators of panel data biased. One solution to this problem is to first difference the model and to use lags of the dependent variable as instruments for the lagged dependent variable. Our solution is to use the GMM procedure of Arellano and Bond (1991). This makes use of the fact that values of the dependent variable lagged two periods or more are

\footnotetext{
${ }^{11}$ The Sachs and Warner (1995) openness indicator is a dummy variable taking a value of zero if the economy was "closed" according to any of five criteria. These being that average tariff rates are higher than 40 percent, NTBs covered on average more than 40 percent of imports, the presence of a socialist economic system, state monopolies of major exports or a BMP in excess of 20 percent in either the seventies or eighties. We use this measure because it represents a much broader measure of openness than alternatives such as the trade share in GDP.

${ }^{12}$ Consistency of the GMM estimator requires a lack of second order serial correlation in the dynamic formulation, so tests for this are presented with the results. Overall instrument validity is also examined using a Sargan test of over-identifying restrictions.
} 
valid instruments for the lagged dependent variable. This will generate consistent and efficient estimates of the parameters of interest ${ }^{12}$. The dynamic model that we estimate therefore is:

$$
\begin{aligned}
& \Delta \ln y_{i t}=\alpha \Delta \ln y_{i, t-1}+\beta_{1} \Delta \ln S P I L L_{i t}+\beta_{2} \ln y_{i, 65}+\beta_{3}\left(\frac{\operatorname{Inv}}{G D P}\right)_{i t}+\beta_{4} \Delta \ln P O P_{i t}+ \\
& \beta_{5} S E C 25_{i, 65}+\beta_{6} \Delta \ln T T I_{i t}+\beta_{7} S A C H S_{i t}+\Delta \varepsilon_{i t}
\end{aligned}
$$

where $y_{i, t-1}$ are lags of the dependent variable.

\section{B. Constructing Foreign Knowledge Stocks}

We construct knowledge stocks for each of the five OECD countries that represent our "donors" by cumulating past (total manufacturing) R\&D expenditure, as proposed by Griliches (1979). Let $K_{d t}$ denote the stock of knowledge of donor $d$ at time $t$. To create alternative measures of the spillover of these knowledge stocks to each "recipient" through trade, the $K_{d t}$ are then weighted in various ways, reflecting different interpretations of the nature of the spillover. The underlying notion is that a unit of imports is a "message" that contains information on the "knowledge" used to produce it. If knowledge is a (pure) public good in the donor, a representative unit of imports can be viewed as giving information on all of $K_{d t}$. But if knowledge is a (pure) private good in the donor, then the representative unit of imports is better viewed as only giving information on a proportion of this knowledge, say $K_{d t} / Q_{d t}$, where $Q_{d t}$ is the level of GDP in the donor at time $t$.

The second issue is the degree of "publicness" of the information transferred in the recipient. If this information is a public good then it will be available to all agents in the recipient. But if it is a private good, then its availability will be limited to a few agents in the recipient. In this case we need to "scale" the information transfer to get the spillover effect on the recipient economy, and there are two alternative bases we can use for this purpose. One is the total volume of imports of the recipient, in which case the important feature is information transferred per unit of imports. The alternative is recipient output, in which case the information transferred is distributed across the economic activity in the economy.

Were information on donor knowledge stocks to be independent of the volume of trade, all recipients would benefit equally from any knowledge spillovers, since they all trade with our group of donors. Such an outcome is both uninteresting and, more importantly, unlikely. More realistically the volume of trade should feature 
in the spillover variable, since the larger the number of messages, the more information that is potentially available. We therefore construct four alternative measures, including bilateral trade flows in each case and, in some cases, deflating by donor output where "knowledge" is a private good in the donor, and by recipient output (or imports) where the knowledge spillover is a private good in the recipient ${ }^{13}$.

We begin with those measures that have been used in the empirical literature. Suppose that knowledge is a public good in the donor, and that the spillover from each donor depends on the level of trade with that donor and the level of the donor's knowledge stocks. Suppose further that the spillover is a private good in the recipient. This approach gives us two measures corresponding to those employed by $\mathrm{CH}$ and $\mathrm{CHH}$. The first deflates the knowledge stocks by the share of imports of each donor in total imports of the recipient $\left(M_{r t}\right)$, yielding

$$
M \bar{K} S_{r t}=\sum_{d} \frac{M_{d r t} K_{d t}}{M_{r t}}=\sum_{d} \theta_{d r t} K_{d t}
$$

where $M_{d r t}$ are (total manufacturing) imports from donor $d$ to recipient $r$, and $\theta_{d r t}$ is the share of donor $d$ in total (manufacturing) imports into recipient $r$, at time $t$. Here the spillover depends on the level of knowledge embodied in the average unit of imports. $\mathrm{CH}$ argue for the use of bilateral share weights by analogy to Terleckyj's (1974) use of input-output weights to model how R\&D is imported across industries. As Coe and Helpman recognise, this formulation leaves no role for the volume of imports, since the shares add up to one. But where two recipients have the same donor composition of imports, one might expect the spillover to be larger in that country which imports more relative to its size (GDP). This is captured by our second measure, which deflates the trade weighted knowledge stocks by the total GDP of the recipient $\left(Q_{r t}\right)$, yielding

$$
Q \bar{K} S_{r t}=\sum_{d} \frac{M_{d r t} \cdot K_{d t}}{Q_{r t}}=\frac{M_{r t}}{Q_{r t}} \sum_{d} \theta_{d r t} K_{d t}
$$

\footnotetext{
${ }^{13}$ Note that while both knowledge stocks and knowledge spillovers can be public goods, the latter would appear to be inherently more public than the former. Given the differences in institutions, sophistication of infrastructure, and definition and enforcement of property rights etc. between developed donors and developing recipients, it is not difficult to imagine that the degree of "publicness" differs between the two.

${ }^{14}$ In fact the preferred specification of Coe and Helpman, $\mathrm{CHH}$ and others is a variant of (1Q) that is the product of the recipient's import share $\left(M_{r t} / Q_{r t}\right)$ and the log of the trade share weighted knowledge stocks.
} 
Interestingly, if we consider the opposite case, where knowledge is viewed as a private good in the donor country, but the knowledge spillover is a public good in the recipient, we have the specification proposed by Lichtenberg and van Pottelsberghe de la Potterie (1998). Now the formulation is

$$
K \bar{S}_{r t}=\sum_{d} M_{d r t} \cdot \frac{K_{d t}}{Q_{d t}}=M_{r t} \sum_{d} \theta_{d r t} \cdot \frac{K_{d t}}{Q_{d t}}
$$

where we can think of $K_{d t} / Q_{d t}$ as the intensity of knowledge embodied in the relevant imports. Their proposal arises from the observation that the foreign knowledge stocks as specified by Coe and Helpman are sensitive to aggregation, since a merger between donor countries would always increase the measured stock of knowledge, yet it is not clear why such a merger would be expected to increase the level of knowledge in the world. Specification (5) removes the importance of the scale of the donor economy from the trade weighted knowledge stock

This leaves two further measures that are untested to date. If it were appropriate to view both knowledge and knowledge spillovers as public goods, the relevant measure becomes

$$
\overline{K S}_{r t}=\sum_{d} M_{d r t} K_{d t}=M_{r t} \cdot \sum_{d} \theta_{d r t} \cdot K_{d t}
$$

Finally, it may be that knowledge stocks and spillovers are both private goods. As above we have two possible deflators for the trade weighted knowledge stocks. If we use the total imports of the recipient, we have

$$
M K S_{r t}=\sum_{d} \frac{M_{d r t} K_{d t}}{M_{r t} Q_{d t}}=\sum_{d} \theta_{d r t} \frac{K_{d t}}{Q_{d t}}
$$

While if we use recipient GDP as the deflator, the relevant measure is

$$
Q K S_{r t}=\sum_{d} \frac{M_{d r t} K_{d t}}{Q_{d t} Q_{r t}}=\frac{M_{r t}}{Q_{r t}} \sum_{d} \theta_{d r t} \frac{K_{d t}}{Q_{d t}}
$$

These are the alternative measures of foreign knowledge spillovers that are considered below. In each case the weights we use relate to total manufacturing imports ${ }^{15}$ from these five donors to the relevant recipient.

\footnotetext{
${ }^{15}$ The import data are total manufacturing exports from the donor to the recipient and are taken from the OECD publication, International Trade by Commodity Statistic.
} 


\section{Results}

Data was collected on all variables for all 52 countries between 1976 and 1990 . Due to first differencing however we lose one observation for each country ${ }^{16}$. The results from the static model are reported in Tables 1 and 2, while Tables 3 and 4 reports the results from the dynamic model.

If we begin with the static results in Table 1, we find that the majority of the core variables in the model are of the expected sign and significant. This is true for the ratio of investment to GDP, initial GDP, secondary schooling and to a lesser degree population growth. The coefficient on the terms of trade variable tends to have the expected sign, but is never significant. The coefficients on the core variables tend to be stable across specifications. Turning to the coefficients on the spillover variables, we find positive and significant coefficients in four specifications (namely 4, 5, 6 and 8) and negative and significant coefficients in the remaining two ( 3 and 7 ). As we note below, the negative coefficients are incon-

Table 1. Results from the Static Model 1

\begin{tabular}{|c|c|c|c|c|c|c|c|}
\hline & Base & 4 & 3 & 5 & 6 & 8 & 7 \\
\hline Spillover & & 0.02 & -0.06 & 0.07 & 0.05 & 0.03 & -0.13 \\
& & $(2.4)^{* *}$ & $(-2.74)^{* * *}$ & $(4.82)^{* * *}$ & $(5.01)^{* * *}$ & $(2.62)^{* * *}$ & $(-4.25)^{* * *}$ \\
INV/GDP & 0.13 & 0.12 & 0.13 & 0.11 & 0.11 & 0.12 & 0.13 \\
& $(2.68)^{* * *}$ & $(2.62)^{* * *}$ & $(2.71)^{* * *}$ & $(2.53)^{* *}$ & $(2.47)^{* *}$ & $(2.64)^{* * *}$ & $(2.53)^{* *}$ \\
GDP65 & -0.01 & -0.01 & -0.01 & -0.01 & -0.01 & -0.01 & -0.01 \\
& $(-5.93)^{* * *}$ & $(-6.07)^{* * *}$ & $(-5.76)^{* * *}$ & $(-6.29)^{* * *}$ & $(-6.08)^{* * *}$ & $(-6.26)^{* * *}$ & $(-5.37)^{* * *}$ \\
DPOP & -0.74 & -0.74 & -0.75 & -0.71 & -0.74 & -0.72 & -0.81 \\
& $(-1.66)^{*}$ & $(-1.64)^{*}$ & $(-1.69)^{*}$ & $(-1.73)^{*}$ & $(-1.73)^{*}$ & $(-1.61)$ & $(-1.69)^{*}$ \\
SEC25 & 0.001 & 0.001 & 0.001 & 0.001 & 0.001 & 0.001 & 0.001 \\
& $(2.72)^{* * *}$ & $(2.77)^{* * *}$ & $(2.71)^{* * *}$ & $(3.02)^{* * *}$ & $(2.82)^{* * *}$ & $(2.87)^{* * *}$ & $(2.4)^{* *}$ \\
DTTI & 0.01 & 0.01 & 0.01 & -0.001 & 0.003 & 0.005 & 0.007 \\
& $(0.48)$ & $(0.36)$ & $(0.35)$ & $(-0.06)$ & $(0.16)$ & $(0.26)$ & $(0.31)$ \\
Constant & 0.07 & 0.07 & 0.07 & 0.07 & 0.07 & 0.07 & 0.07 \\
Wald Test & $(4.22)^{* * *}$ & $(4.44)^{* * *}$ & $(4.21)^{* * *}$ & $(4.82)^{* * *}$ & $(4.52)^{* * *}$ & $(4.67)^{* * *}$ & $(3.91)^{* * *}$ \\
$1^{\text {st }}$ Order Serial & $41.67 * * *$ & $70.86^{* * *}$ & $58.73 * * *$ & $120.87 * * *$ & $103.98 * * *$ & $84.59 * * *$ & $47.62 * * *$ \\
Correlation & $3.09 * * *$ & $2.86^{* * * *}$ & $3.06 * * *$ & $2.38 * *$ & $2.54 * *$ & $2.76 * * *$ & $3.0 * * *$ \\
$2^{\text {nd }}$ Order Serial & & & & & & & \\
Correlation & 0.42 & 0.36 & 0.6 & 0.34 & 0.27 & 0.37 & 0.71 \\
\hline
\end{tabular}

Note: All models are estimated using robust standard errors. Values in parentheses are t-statistics. $* * *, * *, *$ indicate significance at the 1,5 and 10 percent levels respectively.

\footnotetext{
${ }^{16}$ Much of the data used was taken from the dataset of Greenaway, Morgan and Wright (1998). R\&D data was taken from the OECD ANBERD dataset.
} 
sistent with the interpretation of this variable as a "knowledge spillover", but are not unprecedented. $\mathrm{CHH}$ often find that when the knowledge stocks are weighted by the share of trade, the coefficient on the spillover variable is negative. They only find consistently positive and significant coefficients on the spillover variable when the spillover depends upon the level of trade. These results therefore confirm the results of $\mathrm{CHH}$ and suggest that the level of trade is important in facilitating the diffusion of knowledge.

In Table 2, we add the Sachs and Warner measure of openness to the estimated growth model. Its inclusion has little impact upon the size and significance of the core variables in the model, except for population, which falls in absolute size and becomes insignificant. The inclusion of the openness measure also has no impact upon the size and significance of the spillover variables. We again find positive and significant coefficients in the case of specifications 4, 5, 6 and 8, and negative and significant coefficients in the case of specifications 3 and 7. The coefficient on the openness measure is itself positive and significant. This is in contrast to Coe and Helpman and $\mathrm{CHH}$ who find negative coefficients on their measures of

Table 2. Results from the Static Model 2

\begin{tabular}{|c|c|c|c|c|c|c|c|}
\hline & Base & 4 & 3 & 5 & 6 & 8 & 7 \\
\hline Spillover & & $\begin{array}{c}0.02 \\
(2.14)^{* *}\end{array}$ & $\begin{array}{c}-0.06 \\
(-2.69) * * *\end{array}$ & $\begin{array}{c}0.07 \\
(5.36)^{* * * *}\end{array}$ & $\begin{array}{c}0.05 \\
(5.03)^{* * *}\end{array}$ & $\begin{array}{c}0.03 \\
(2.36)^{* *}\end{array}$ & $\begin{array}{c}-0.14 \\
(-4.37) * * *\end{array}$ \\
\hline INV/GDP & $\begin{array}{c}0.12 \\
(2.81)^{* * *}\end{array}$ & $\begin{array}{c}0.12 \\
(2.75)^{* * *}\end{array}$ & $\begin{array}{c}0.12 \\
(2.86) * * *\end{array}$ & $\begin{array}{c}0.1 \\
(2.63) * * *\end{array}$ & $\begin{array}{c}0.11 \\
(2.57)^{* *}\end{array}$ & $\begin{array}{c}0.12 \\
(2.77)^{* * *}\end{array}$ & $\begin{array}{c}0.12 \\
(2.63)^{* * *}\end{array}$ \\
\hline GDP65 & $\begin{array}{c}-0.01 \\
(-5.9) * * *\end{array}$ & $\begin{array}{c}-0.01 \\
(-6.05)^{* * *}\end{array}$ & $\begin{array}{c}-0.01 \\
(-5.72)^{* * *}\end{array}$ & $\begin{array}{c}-0.01 \\
(-6.16)^{* * *}\end{array}$ & $\begin{array}{c}-0.01 \\
(-6.04)^{* * * *}\end{array}$ & $\begin{array}{c}-0.01 \\
(-6.17) * * *\end{array}$ & $\begin{array}{c}-0.01 \\
(-5.46) * * *\end{array}$ \\
\hline DPOP & $\begin{array}{c}-0.58 \\
(-1.38)\end{array}$ & $\begin{array}{c}-0.58 \\
(-1.38)\end{array}$ & $\begin{array}{l}-0.59 \\
(-1.4)\end{array}$ & $\begin{array}{c}-0.59 \\
(-1.52)\end{array}$ & $\begin{array}{c}-0.61 \\
(-1.49)\end{array}$ & $\begin{array}{c}-0.57 \\
(-1.36)\end{array}$ & $\begin{array}{c}-0.64 \\
(-1.42)\end{array}$ \\
\hline SEC25 & $\begin{array}{c}0.001 \\
(2.49)^{* * *}\end{array}$ & $\begin{array}{c}0.001 \\
(2.57)^{* *}\end{array}$ & $\begin{array}{c}0.001 \\
(2.48)^{* *}\end{array}$ & $\begin{array}{c}0.001 \\
(2.84) * * *\end{array}$ & $\begin{array}{c}0.001 \\
(2.66) * * *\end{array}$ & $\begin{array}{c}0.001 \\
(2.65) * * *\end{array}$ & $\begin{array}{c}0.001 \\
(2.17)^{* *}\end{array}$ \\
\hline DTTI & $\begin{array}{c}0.01 \\
(0.44)\end{array}$ & $\begin{array}{c}0.01 \\
(0.34)\end{array}$ & $\begin{array}{c}0.01 \\
(0.32)\end{array}$ & $\begin{array}{l}-0.001 \\
(-0.05)\end{array}$ & $\begin{array}{l}0.003 \\
(0.15)\end{array}$ & $\begin{array}{c}0.01 \\
(0.26)\end{array}$ & $\begin{array}{c}0.01 \\
(0.27)\end{array}$ \\
\hline Sachs & $\begin{array}{c}0.023 \\
(6.22)^{* * *}\end{array}$ & $\begin{array}{c}0.022 \\
(5.99)^{* * *}\end{array}$ & $\begin{array}{c}0.023 \\
(6.28)^{* * *}\end{array}$ & $\begin{array}{c}0.017 \\
(4.87)^{* * *}\end{array}$ & $\begin{array}{c}0.019 \\
(5.43)^{* * *}\end{array}$ & $\begin{array}{c}0.02 \\
(5.83)^{* * *}\end{array}$ & $\begin{array}{c}0.02 \\
(6.43)^{* * *}\end{array}$ \\
\hline Constant & $\begin{array}{c}0.06 \\
(3.76)^{* * *}\end{array}$ & $\begin{array}{c}0.06 \\
(3.99)^{* * *}\end{array}$ & $\begin{array}{c}0.06 \\
(3.76)^{* * *}\end{array}$ & $\begin{array}{c}0.06 \\
(4.4)^{* * *}\end{array}$ & $\begin{array}{c}0.06 \\
(4.09) * * *\end{array}$ & $\begin{array}{c}0.06 \\
(4.22)^{* * *}\end{array}$ & $\begin{array}{c}0.06 \\
(3.5)^{* * *}\end{array}$ \\
\hline Wald Test & $139.14 * * *$ & $157.56 * * *$ & $159.86 * * *$ & $210.75 * * *$ & $201.85 * * *$ & $165.37 * * *$ & $134.96 * * *$ \\
\hline $\begin{array}{c}1^{\text {st }} \text { Order Serial } \\
\text { Correlation }\end{array}$ & $2.92 * * *$ & $2.69 * * *$ & $2.89 * * *$ & $2.18 * *$ & $2.33 * *$ & $2.59 * * *$ & $2.8 * * *$ \\
\hline $\begin{array}{c}2^{\text {nd }} \text { Order Serial } \\
\text { Correlation }\end{array}$ & -0.23 & -0.23 & -0.05 & -0.09 & -0.22 & -0.18 & 0.07 \\
\hline
\end{tabular}

Note: All models are estimated using robust standard errors. Values in parentheses are t-statistics. $* * *, * *, *$ indicate significance at the 1,5 and 10 percent levels respectively. 
Table 3. Results from the Dynamic Model 1

\begin{tabular}{|c|c|c|c|c|c|c|c|}
\hline & Base & 4 & 3 & 5 & 6 & 8 & 7 \\
\hline$y_{t-1}$ & $\begin{array}{c}0.24 \\
(4.54)^{* * *}\end{array}$ & $\begin{array}{c}0.22 \\
(4.03)^{* * *}\end{array}$ & $\begin{array}{c}0.24 \\
(4.38)^{* * *}\end{array}$ & $\begin{array}{c}0.23 \\
(6.08)^{* * *}\end{array}$ & $\begin{array}{c}0.26 \\
(5.11)^{* * *}\end{array}$ & $\begin{array}{c}0.24 \\
(4.39)^{* * *}\end{array}$ & $\begin{array}{c}0.25 \\
(7.3)^{* * *}\end{array}$ \\
\hline$y_{t-2}$ & $\begin{array}{c}-0.08 \\
(-4.53)^{* * *}\end{array}$ & $\begin{array}{c}-0.09 \\
(-4.72)^{* * *}\end{array}$ & $(-3.32)^{* * * *}$ & $\begin{array}{c}-0.07 \\
(-2.4)^{* *}\end{array}$ & $\begin{array}{c}-0.08 \\
(-3.5)^{* * *}\end{array}$ & $\begin{array}{c}-0.08 \\
(-4.21)^{* * *}\end{array}$ & $\begin{array}{c}-0.09 \\
(-5.25)^{* * *}\end{array}$ \\
\hline Spillover & & $\begin{array}{c}0.01 \\
(0.78)\end{array}$ & $\begin{array}{c}-0.05 \\
(-2.52) * *\end{array}$ & $\begin{array}{c}0.06 \\
(6.45)^{* * *}\end{array}$ & $\begin{array}{c}0.03 \\
(2.93)^{* * *}\end{array}$ & $\begin{array}{c}0.02 \\
(1.42)\end{array}$ & $\begin{array}{c}-0.08 \\
(-1.77)^{*}\end{array}$ \\
\hline$I N V / G D P$ & $\begin{array}{c}0.17 \\
(4.47) * * *\end{array}$ & $\begin{array}{c}0.21 \\
(3.68) * * *\end{array}$ & $\begin{array}{c}0.14 \\
(3.49)^{* * *}\end{array}$ & $\begin{array}{c}0.21 \\
(5.85)^{* * *}\end{array}$ & $\begin{array}{c}0.19 \\
(3.83)^{* * *}\end{array}$ & $\begin{array}{c}0.2 \\
(3.85)^{* * *}\end{array}$ & $\begin{array}{c}0.17 \\
(3.87)^{* * *}\end{array}$ \\
\hline GDP65 & $\begin{array}{c}-0.01 \\
(-3.94) * * *\end{array}$ & $\begin{array}{c}-0.01 \\
(-3.49) * * *\end{array}$ & $\begin{array}{c}-0.01 \\
(-3.63)^{* * * *}\end{array}$ & $\begin{array}{c}-0.01 \\
(-3.39)^{* * * *}\end{array}$ & $\begin{array}{c}-0.01 \\
(-3.39) * * *\end{array}$ & $\begin{array}{c}-0.01 \\
(-2.89)^{* * * *}\end{array}$ & $\begin{array}{c}-0.01 \\
(-3.81)^{* * *}\end{array}$ \\
\hline$D P O P$ & $\begin{array}{c}-0.3 \\
(-0.93)\end{array}$ & $\begin{array}{l}-0.33 \\
(-1.04)\end{array}$ & $\begin{array}{l}-0.37 \\
(-1.25)\end{array}$ & $\begin{array}{l}-0.32 \\
(-0.94)\end{array}$ & $\begin{array}{l}-0.38 \\
(-1.03)\end{array}$ & $\begin{array}{l}-0.41 \\
(-1.18)\end{array}$ & $\begin{array}{l}-0.28 \\
(-0.73)\end{array}$ \\
\hline SEC25 & $\begin{array}{c}0.001 \\
(3.16)^{* * *}\end{array}$ & $\begin{array}{c}0.001 \\
(2.14)^{* *}\end{array}$ & $\begin{array}{c}0.001 \\
(3.63)^{* * *}\end{array}$ & $\begin{array}{l}0.001 \\
(1.73)^{*}\end{array}$ & $\begin{array}{c}0.001 \\
(2.03)^{* *}\end{array}$ & $\begin{array}{c}0.001 \\
(1.69)^{*}\end{array}$ & $\begin{array}{c}0.001 \\
(3.08)^{* * *}\end{array}$ \\
\hline DTTI & $\begin{array}{c}0.04 \\
(2.28)^{* *}\end{array}$ & $\begin{array}{c}0.05 \\
(2.43)^{* *}\end{array}$ & $\begin{array}{c}0.02 \\
(0.99)\end{array}$ & $\begin{array}{c}0.05 \\
(2.56)^{* *}\end{array}$ & $\begin{array}{c}0.04 \\
(2.54)^{* *}\end{array}$ & $\begin{array}{c}0.05 \\
(2.46)^{* *}\end{array}$ & $\begin{array}{c}0.03 \\
(2.09)^{* *}\end{array}$ \\
\hline Constant & $\begin{array}{c}0.02 \\
(1.43)\end{array}$ & $\begin{array}{c}0.01 \\
(0.65)\end{array}$ & $\begin{array}{c}0.02 \\
(1.42)\end{array}$ & $\begin{array}{c}0.01 \\
(0.65)\end{array}$ & $\begin{array}{c}0.01 \\
(0.88)\end{array}$ & $\begin{array}{c}0.01 \\
(0.65)\end{array}$ & $\begin{array}{c}0.02 \\
(0.98)\end{array}$ \\
\hline Wald Test & $150.68 * * *$ & $153.27 * * *$ & $285.58 * * *$ & $317.97 * * *$ & $184.37 * * *$ & $151.75 * * *$ & $279.54 * * *$ \\
\hline $\begin{array}{c}1^{\text {st }} \text { Order Serial } \\
\text { Correlation }\end{array}$ & 0.49 & 0.62 & 0.55 & -0.12 & -0.15 & 0.23 & 0.56 \\
\hline $\begin{array}{c}2^{\text {nd }} \text { Order Serial } \\
\text { Correlation }\end{array}$ & 0.99 & 1.24 & 0.98 & 0.79 & 0.79 & 1.01 & 1.1 \\
\hline Sargan Test & 44.09 & 42.65 & 44.79 & 44.84 & 45.71 & 43.71 & 43.87 \\
\hline
\end{tabular}

Note: All models are estimated using robust standard errors. Values in parentheses are t-statistics. $* * *, * *, *$ indicate significance at the 1,5 and 10 percent levels respectively.

openness, and suggests that openness has an impact on growth in addition to any indirect role in knowledge diffusion ${ }^{17}$.

Tables 3 and 4 report the results from estimating the dynamic model. The Sargan test is satisfied and the test for second order correlation is rejected, suggesting that the equation is appropriately specified. Beginning with Table 3 , we see that the coefficients on most of the core variables change very little from the static model, although the coefficient on the investment to GDP ratio increases somewhat and the coefficient on the terms of trade index is often now significant. The signs of the coefficients on the spillover variables remain the same, with

\footnotetext{
${ }^{17}$ Their use of the imports to GDP ratio to measure openness raises the potential for multicollinearity between the openness and spillover variables, which may explain their finding. It should be noted that the Sachs and Warner measure has been criticised as a measure of "openness to international trade" by Rodriguez and Rodrik (1999), and it could well be capturing other aspects of openness here.
} 
positive coefficients in four cases and negative coefficients in the remaining two. The size of the coefficients on the spillover variables do not alter a great deal from the static specification, although the coefficients are not significant in specifications 4 and 8 when the model is estimated dynamically. Table 4 estimates the dynamic model with the openness measure included. The coefficients on the core variables are broadly similar, except that population growth now becomes positive and often significant. Turning to the spillover variables, the coefficients on each

Table 4. Results from the Dynamic Model 2

\begin{tabular}{|c|c|c|c|c|c|c|c|}
\hline & Base & 4 & 3 & 5 & 6 & 8 & 7 \\
\hline$y_{t-1}$ & $\begin{array}{c}0.21 \\
(6.52)^{* * *}\end{array}$ & $\begin{array}{c}0.22 \\
(6.77)^{* * *}\end{array}$ & $\begin{array}{c}0.2 \\
(5.99)^{* * *}\end{array}$ & $\begin{array}{c}0.18 \\
(5.39)^{* * *}\end{array}$ & $\begin{array}{c}0.22 \\
(6.04)^{* * *}\end{array}$ & $\begin{array}{c}0.2 \\
(6.24)^{* * *}\end{array}$ & $\begin{array}{c}0.24 \\
(6.92)^{* * *}\end{array}$ \\
\hline$y_{t-2}$ & $\begin{array}{c}-0.11 \\
(-5.46)^{* * *}\end{array}$ & $\begin{array}{c}-0.1 \\
(-5.64) * * *\end{array}$ & $\begin{array}{c}-0.09 \\
(-4.16)^{* * *}\end{array}$ & $\begin{array}{c}-0.08 \\
(-3.62) * * *\end{array}$ & $\begin{array}{c}-0.1 \\
(-4.72)^{* * *}\end{array}$ & $\begin{array}{c}-0.1 \\
(-5.0)^{* * *}\end{array}$ & $\begin{array}{c}-0.11 \\
(-5.5)^{* * *}\end{array}$ \\
\hline Spillover & & $\begin{array}{c}0.01 \\
(0.65)\end{array}$ & $\begin{array}{c}-0.04 \\
(-2.05)^{* *}\end{array}$ & $\begin{array}{c}0.06 \\
(5.58)^{* * * *}\end{array}$ & $\begin{array}{c}0.03 \\
(3.36)^{* * *}\end{array}$ & $\begin{array}{c}0.02 \\
(1.28)\end{array}$ & $\begin{array}{c}-0.17 \\
(-4.66) * * *\end{array}$ \\
\hline$I N V / G D P$ & $\begin{array}{c}0.15 \\
(4.07)^{* * *}\end{array}$ & $\begin{array}{c}0.15 \\
(4.25)^{* * * *}\end{array}$ & $\begin{array}{c}0.13 \\
(3.78) * * *\end{array}$ & $\begin{array}{c}0.19 \\
(5.22)^{* * *}\end{array}$ & $\begin{array}{c}0.18 \\
(4.46)^{* * *}\end{array}$ & $\begin{array}{c}0.16 \\
(4.27)^{* * *}\end{array}$ & $\begin{array}{c}0.14 \\
(4.19)^{* * *}\end{array}$ \\
\hline GDP65 & $\begin{array}{c}-0.02 \\
(-5.15)^{* * * *}\end{array}$ & $\begin{array}{c}-0.01 \\
(-4.42) * * *\end{array}$ & $\begin{array}{c}-0.01 \\
(-4.69) * * *\end{array}$ & $\begin{array}{c}-0.01 \\
(-4.13) * * *\end{array}$ & $\begin{array}{c}-0.01 \\
(-4.56)^{* * * *}\end{array}$ & $\begin{array}{c}-0.01 \\
(-4.64) * * *\end{array}$ & $\begin{array}{c}-0.01 \\
(-4.24)^{* * * *}\end{array}$ \\
\hline DPOP & $\begin{array}{c}0.76 \\
(1.76)^{*}\end{array}$ & $\begin{array}{c}0.78 \\
(1.84)^{*}\end{array}$ & $\begin{array}{c}0.67 \\
(1.77)^{*}\end{array}$ & $\begin{array}{c}0.52 \\
(1.41)\end{array}$ & $\begin{array}{c}0.86 \\
(1.96)^{* *}\end{array}$ & $\begin{array}{c}0.73 \\
(1.68)^{*}\end{array}$ & $\begin{array}{c}1.05 \\
(2.4)^{* *}\end{array}$ \\
\hline SEC25 & $\begin{array}{c}0.001 \\
(3.02)^{* * *}\end{array}$ & $\begin{array}{c}0.001 \\
(2.72)^{* * *}\end{array}$ & $\begin{array}{c}0.001 \\
(2.96)^{* * *}\end{array}$ & $\begin{array}{c}0.001 \\
(2.79)^{* * *}\end{array}$ & $\begin{array}{c}0.001 \\
(2.65)^{* * *}\end{array}$ & $\begin{array}{c}0.001 \\
(2.95)^{* * *}\end{array}$ & $\begin{array}{c}0.001 \\
(2.45)^{* *}\end{array}$ \\
\hline DTTI & $\begin{array}{c}0.02 \\
(1.58)\end{array}$ & $\begin{array}{c}0.03 \\
(1.73)^{*}\end{array}$ & $\begin{array}{c}0.02 \\
(1.06)\end{array}$ & $\begin{array}{c}0.07 \\
(3.2)^{* * *}\end{array}$ & $\begin{array}{c}0.05 \\
(2.84)^{* * *}\end{array}$ & $\begin{array}{c}0.03 \\
(2.02)^{* *}\end{array}$ & $\begin{array}{c}0.02 \\
(1.35)\end{array}$ \\
\hline SACHS & $\begin{array}{c}0.03 \\
(6.52)^{* * *}\end{array}$ & $\begin{array}{c}0.03 \\
(6.26)^{* * *}\end{array}$ & $\begin{array}{c}0.04 \\
(6.53) * * *\end{array}$ & $\begin{array}{c}0.03 \\
(4.82)^{* * *}\end{array}$ & $\begin{array}{c}0.03 \\
(6.29)^{* * * *}\end{array}$ & $\begin{array}{c}0.03 \\
(5.5)^{* * *}\end{array}$ & $\begin{array}{c}0.04 \\
(6.81)^{* * *}\end{array}$ \\
\hline Constant & $\begin{array}{c}0.02 \\
(1.71)^{*}\end{array}$ & $\begin{array}{c}0.02 \\
(1.04)\end{array}$ & $\begin{array}{c}0.03 \\
(1.58)\end{array}$ & $\begin{array}{l}0.004 \\
(0.31)\end{array}$ & $\begin{array}{c}0.01 \\
(0.53)\end{array}$ & $\begin{array}{c}0.02 \\
(1.18)\end{array}$ & $\begin{array}{c}0.01 \\
(0.38)\end{array}$ \\
\hline Wald Test & $199.35^{* * *}$ & $220.98 * * *$ & $398.05 * * *$ & $206.65 * * *$ & $181.19 * * *$ & $201.44 * * *$ & $245.31 * * *$ \\
\hline $\begin{array}{c}1^{\text {st }} \text { Order Serial } \\
\text { Correlation }\end{array}$ & 0.63 & 0.3 & 0.64 & -0.07 & 0.08 & 0.44 & 0.61 \\
\hline $\begin{array}{c}2^{\text {nd }} \text { Order Serial } \\
\text { Correlation }\end{array}$ & 0.98 & 0.89 & 0.78 & 0.86 & 1.09 & 0.96 & 1.22 \\
\hline Sargan Test & 44.67 & 43.02 & 43.44 & 41.35 & 41.81 & 42.96 & 43.53 \\
\hline
\end{tabular}

Note: All models are estimated using robust standard errors. Values in parentheses are t-statistics. $* * *, * *, *$ indicate significance at the 1,5 and 10 percent levels respectively.

Table 5. Long-Run Impact of Foreign Knowledge Spillovers on Growth

\begin{tabular}{|c|c|c|c|c|}
\hline & 4 & 5 & 6 & 8 \\
\hline Without Openness & 0.012 & 0.071 & 0.037 & 0.024 \\
With Openness & 0.011 & 0.067 & 0.034 & 0.022 \\
\hline
\end{tabular}


variable are again of the same signs as previously, and are significant except in specifications 4 and 8 . Once again the openness measure itself is positive and significant.

When we examine the full set of results for the spillover variables, we find that our measures group naturally into three pairs. Our results imply that: first, regardless of whether knowledge is a private or public good in the donor, when the corresponding spillover is deflated by the recipient's total imports (yielding measures 3 and 7), the estimated coefficient is negative and significant. We note that these are the measures that allow for the distribution of trade but not its volume, and that such an outcome is inconsistent with the interpretation of this variable as a knowledge spillover ${ }^{18}$. Second, regardless of whether knowledge is a private or public good in the donor, when the corresponding spillover is deflated by the recipient's GDP (yielding measures 4 and 8), the estimated coefficient is positive but insignificant in the dynamic model. If the spillover is treated as a private good in the recipient, there is only weak evidence that knowledge spillovers affect growth. Third, regardless of whether knowledge is a private or public good in the donor, when the corresponding spillover is treated as a public good in the recipient (yielding measures 5 and 6) the estimated coefficient is positive and significant. For these measures we do have evidence of knowledge spillovers, that appears to be robust.

The coefficients on the knowledge spillover variables in Tables 1 and 2 that depend upon the level of imports imply that a 1 percent increase in the knowledge stock of the developed countries will on average raise growth in the developing countries by between 0.02 and 0.07 percent in the static model. The impact of knowledge spillovers found in the static model therefore are not too dissimilar to those found by $\mathrm{CHH}$ looking at the impact of spillovers on TFP growth.

The coefficients on the spillover variables in the dynamic model are interpreted as giving the short-run impact on growth of knowledge spillovers and suggest that a 1 percent increase in the knowledge stocks of the developed countries will increase growth by between 0.01 and 0.06 percent. In the dynamic model we can also estimate the long-run impact of the spillover variables on the growth of GDP per capita, using the formula $\sum \beta /\left(1-\sum \alpha_{i}\right)$ where $\beta$ is the coefficient on the foreign knowledge variable and $\alpha_{i}$ are the coefficients on the lagged dependent variables. Table 5 reports the estimated long-run impacts of foreign knowledge on

${ }^{18} \mathrm{CHH}$ also find a negative coefficient on 3 . 
growth for the four specifications that result in positive coefficients.

An increase in the knowledge stock in the developed countries of 1 percent would lead on average to an increase in the long-run growth rate of between 0.011 and 0.071 percent depending upon the specification of the spillover variable and whether openness is included in the growth model or not. In general, the estimated short-run and long-run impact of foreign knowledge spillovers are quite similar, which may seem surprising if we expect knowledge to diffuse slowly, therefore having a greater impact on growth in the long-run. It should be noted however, that we are only using 14 years of data to estimate a long-run relationship, it may be that knowledge takes longer than this period of time to diffuse fully. Alternatively, the constructed knowledge stocks may be capturing a form of diffusion that has an immediate impact on growth, for example the use of advanced machinery, which once imported is immediately more productive.

\section{Conclusions}

It has long been thought that foreign knowledge spillovers may be important to the growth process, with trade being one mechanism through which spillovers occur. Endogenous growth theory suggests that a country whose trade partners have high levels of technology should grow faster, since through trade they gain access to the knowledge produced in these countries. Studies have tested for a relationship between productivity and foreign knowledge, where the latter is taken to be cumulative R\&D expenditures. It is assumed that either import shares or import volumes determine access to such knowledge, because international trade allows the importation of products that embody advanced technology and knowledge, and access to information that could otherwise not be acquired. The results of these studies are mixed, and while some evidence in support of foreign knowledge spillovers has been found, it is not universal and debate continues over the appropriate construction and weighting of the spillover measures and the estimation procedures employed.

We test for the presence of spillovers from the five leading OECD economies (in terms of $\mathrm{R} \& \mathrm{D}$ expenditure) to a sample of developing countries, following closely the methodology of $\mathrm{CH}$ and $\mathrm{CHH}$ to construct the variables representing foreign knowledge. We depart from the standard literature in three respects. Firstly, we employed a number of weighting schemes for the knowledge spillover variable in order to draw some inferences as to the nature of the spillover, and to 
test the robustness of the results obtained. Second, we employed a growth model which allows us to more adequately capture other factors that may affect the extent of knowledge spillovers that are not taken account of in TFP calculations. Finally, we employed a dynamic panel model of GDP growth, which had the advantage that it allowed knowledge spillovers to have both a short-run and long-run impact on growth. The problem of non-stationarity of the knowledge stocks is also eliminated using this approach.

A standard growth model was estimated for a sample of 52 developing countries. The results lead to a consistent set of results on knowledge spillovers, in that only those specifications that depend upon the level of imports result in positive coefficients. The strongest support is for cases where knowledge is either a private or public good in the donor, but where the knowledge spillover is a public good in the recipient. The results from the specifications that do depend upon the level of imports suggest that a 1 percent increase in the knowledge stock of the developed countries can increase growth in the developing countries by between 0.01 and 0.07 percent in the short-run. The long-run impact of knowledge spillovers on growth was found to be very similar to that in the short-run. The fact that the initial GDP term remains negative and significant when spillover variables are included suggests that spillovers don't exhaust the advantages of backwardness. A further implication of these results, is that openness affects growth through channels other than knowledge diffusion, a result not found by Coe and Helpman and $\mathrm{CHH}$.

\section{Acknowledgement}

The authors acknowledge comments on an earlier draft of the paper from participants at Conference at Universidad Complutense de Madrid and financial support from The Leverhulme Trust under Programme Grant F114/BF.

Received 2 August 2002, Accepted 1 October 2002

\section{References}

Abramovitz, Moses (1986). "Catching Up, Forging Ahead, and Falling Behind", Journal of Economic History, 46, 385-406.

Arellano, Manuel and Stephen Bond (1991). "Some Tests of Specification for Panel Data: 
Monte Carlo Evidence and an Application to Employment Equations", Review of Economic Studies, 58, 277-297.

Bevan, D., Collier, P. and J. W. Gunning (1993). "Trade Shocks in Developing Countries: Consequences and Policy Responses", European Economic Review, 37, 557-565.

Coe, David T., and Elhanan Helpman (1995). "International R\&D Spillovers", European Economic Review, 39, 859-887.

Coe, David T., Helpman, E., and Alexander W. Hoffmaister (1997). "North-South R\&D Spillovers," Economic Journal, 107, 134-150.

Coe, David T., and Alexander W. Hoffmaister (1999). "Are There International R\&D Spillovers Among Randomly Matched Trade Partners? A Response to Keller", Working Paper of the International Monetary Fund, no. WP/99/18.

Crespo, Jorge, Carmela Martin and Francisco J. Velazquez (2002), "International Technology Diffusion Through Imports and its Impact on Economic Growth", European Economy Group Working Paper 12/2002 Universidad Complutense de Madrid.

Eaton, Jonathan and Samuel Kortum (1999). "International Technology Diffusion: Theory and Measurement", International Economic Review, 40, 537-570.

Evenson, Robert E. and Lakhwinder Singh (1997). "Economic Growth, International Technological Spillovers and Public Policy: Theory and Empirical Evidence from Asia", Economic Growth Center Discussion Paper no. DP777, Yale University.

Funk, Mark F. (2001) "International R\&D Spillovers and Convergence Among OECD Countries", Journal of Economic Integration, 16, 48-65.

Gerschenkron, A (1962). Economic Backwardness in Historical Perspective, Cambridge MA, Belknap Press.

Greenaway, David, Morgan, Wyn and Peter Wright (1997) "Trade Liberalisation and Growth in Developing Countries: Some New Evidence", World Development, 25, 1885-1892.

Greenaway, David, Morgan, Wyn and Peter Wright (1998). "Trade Reform, Adjustment and Growth: What Does the Evidence Tell Us?", Economic Journal, 108, 1547-1561.

Greenaway, David, Morgan, Wyn and Peter Wright (2002). "Trade Liberalisation and Growth in Developing Countries", Journal of Development Economics, 67, 229-244.

Griliches, Zvi (1979). "Issues in Assessing the Contribution of R\&D to Productivity Growth," Bell Journal of Economics, 10, 92-116.

Griliches, Zvi (1984). R\&D, Patents and Productivity, Chicago, University of Chicago Press.

Grossman Gene and Elhanan Helpman (1991). Innovation and Growth in the Global Economy, Cambridge MA, MIT Press.

Kao, Chihwa, Chiang, Min-Hsien and Bangtian Chen (1999). "International R\&D Spillovers: An Application of Estimation and Inference in Panel Cointegration", Oxford Bulletin of Economics and Statistics, 61, 693-711.

Keller, Wolfgang (1998). "Are International R\&D Spillovers Trade-related ? Analyzing Spillovers Among Randomly Matched Trade Partners", European Economic Review, 
42, 1469-1481.

Keller, Wolfgang (2000). "Trade and the Transmission of Technology", World Bank Economic Review, 14, 17-47.

Kuznets, S (1973). Population, Capital and Growth: Selected Essays, New York, W. W. Norton and Company.

Levine, Ross and David Renelt (1992). “A Sensitivity Analysis of Cross-Country Growth Regressions", American Economic Review, 82, 942-963.

Lichtenberg, Frank R., and Bruno van Pottelsberghe de la Potterie (1998). "International R\&D Spillovers A Comment”, European Economic Review, 42, 1483-1491.

Moreno, Ramon and Bharat Trehan (1997). "Location and the Growth of Nations", Journal of Economic Growth, 2, 399-418.

Rodriguez, Francisco and Dani Rodrik (1999). "Trade Policy and Economic Growth: A Skeptics Guide to the Cross-National Evidence", NBER Working Paper no. 7081. Cambridge, MA, NBER.

Sachs, Jeffrey and Andrew Warner (1995). "Economic Reform and the Process of Global Integration", Brookings Papers on Economic Activity, 1, 1-118.

Sala-i-Martin, Xavier (1997). "I Just Ran Two Million Regressions", American Economic Association Papers and Proceedings, 87, 2 (May), 178-183.

Terleckyj, N. E. (1974). Effects of R\&D on the Productivity Growth of Industries, Report no. 140, National Planning Association, Washington DC.

World Bank (1999). World Development Report, Oxford, Oxford University Press.

$\mathrm{Xu}$ Bin and Jianmao Wang (2000) “Trade, FDI and International Technology Diffusion", Journal of Economic Integration, 15, 585-601. 